Supplementary Information

\title{
Chemical Mechanism of the Phosphotriesterase from Sphingobium sp. Strain TCM1, an Enzyme Capable of Hydrolyzing Organophosphate Flame Retardants
}

Andrew N. Bigley, Dao Feng Xiang, Zhongjie Ren, Haoran Xue, Kenneth G. Hull, Daniel Romo, and Frank M. Raushel ${ }^{*}$ 


\section{Materials and Methods}

Materials. $P d$-PTE was expressed and purified as previously described. ${ }^{1}$ All enzymes were stored at $-80{ }^{\circ} \mathrm{C}$ prior to use. In general, chemicals were from Sigma Aldrich unless otherwise noted. SDS-Page precast gels were from Bio-Rad. Paraoxon was from Sigma.

Sb-PTE Expression and Purification. The codon-optimized gene for Sb-PTE (gi|664819019) was purchased from GenScript (Piscataway, NJ), and subcloned into pET30a (EMD Millipore) using the NdeI and XhoI restriction sites to express as C-terminal Histagged protein. The final construct was transformed into BL21 (DE3) cells (EMD Millipore) and single colonies were used to inoculate $6 \mathrm{~mL}$ cultures of $\mathrm{LB}$, which were grown for nine hours at $37{ }^{\circ} \mathrm{C}$. The $6 \mathrm{~mL}$ cultures were subsequently used to inoculate $1 \mathrm{~L}$ cultures of Terrific Broth supplemented with $1.0 \mathrm{mM} \mathrm{Mn}(\mathrm{Ac})_{2}$ and then grown at $30{ }^{\circ} \mathrm{C}$ for 14 hours. The temperature was reduced to room temperature and growth continued for an additional 4-6 hours. The optimal growth time was determined by tracking paraoxonase activity from the crude cell lysate. Once optimal catalytic activity was achieved, the cells were harvested by centrifugation and stored at $-80{ }^{\circ} \mathrm{C}$ prior to purification of the enzyme.

Cell pellets $(\sim 10 \mathrm{~g})$ were resuspended in $50 \mathrm{~mL}$ of binding buffer $(20 \mathrm{mM}$ HEPES, $\mathrm{pH}$ $7.9,0.50 \mathrm{M} \mathrm{NaCl}$, and $10 \mathrm{mM}$ imidazole) and then disrupted by sonication using a Branson Sonifier 450. The cell lysate was clarified by centrifugation before being passed through a 0.22 $\mu \mathrm{M}$ syringe filter (VWR) and then loaded onto a 5-mL HisTrap HP column (GE Healthcare) attached to an NGC Liquid Chromatography system (Bio-Rad) previously equilibrated with binding buffer. The His-tagged protein was eluted with a 0-50\% gradient with elution buffer (20 $\mathrm{mM}$ HEPES, $\mathrm{pH} 7.9,0.25 \mathrm{M} \mathrm{NaCl}$, and $0.50 \mathrm{M}$ imidazole). The fractions with paraoxonase activity were combined and concentrated. The buffer was exchanged using a PD-10 desalting column (GE Healthcare) equilibrated with $20 \mathrm{mM}$ HEPES, pH 8.0. The final protein solution was brought to $100 \mathrm{mM} \mathrm{NaCl}$ to maintain protein stability. Protein purity was judged to be greater than $95 \%$ based on SDS-PAGE.

${ }^{18}$ O-labeling of Sb-PTE Protein. $50 \mu \mathrm{L}$ samples of $220 \mu \mathrm{M}$ Sb-PTE were dried in-vacuo at room temperature. Similarly, samples of $20 \mu \mathrm{L} 0.5 \mathrm{M} \mathrm{CHES}(\mathrm{pH}$ 9) and, separately, $66 \mu \mathrm{L}$ of $8.4 \mathrm{mM}$ paraoxon were dried to completion. Samples were then reconstituted and combined in a total of $120 \mu \mathrm{L}$ of ${ }^{18} \mathrm{O}$ labled or unlabeled water as a control. The samples were incubated at room temperature until the hydrolysis of the paraoxon was complete $(\sim 2 \mathrm{hr})$. The protein was run on SDS PAGE gel and the appropriate bands were digested in-gel with trypsin prior to MS analysis as previously described. ${ }^{2}$ Peptide coverage for control reaction was $85 \%$ while coverage for ${ }^{18} \mathrm{O}$ experiment was $87 \%$ (Table S1). In both cases the peptide containing the proposed active site aspartate (Asp-478) was observed.

${ }^{18}$ O-labeling of Reaction Products by Sb-PTE ${ }^{18} \mathrm{O}$ incorporation into the reaction products of $S b$-PTE were tested under single and multi-turnover conditions. $100 \mu \mathrm{L}$ reactions were in run in $60 \%{ }^{18} \mathrm{O}$ labeled water with $20 \mathrm{mM} \mathrm{NH}_{4} \mathrm{HCO}_{3}(\mathrm{pH} 9.0$ ). For single turnover conditions $50 \mu \mathrm{M}$ paraoxon was used with $150 \mu \mathrm{M}$ Sb-PTE. For multi-turnover conditions 500 
$\mu \mathrm{M}$ paraoxon was used with $50 \mu \mathrm{M} S b$-PTE. Reactions were run overnight and protein filtered out using a Viaspin 500 centrifugal filtration device (GE Healthcare). Reaction products were analyzed by mass spectrometry using by Thermo Scientific Q Exactive mass spectrometer. The samples were applied to the mass spectrometer by direct injection at a flow rate of $200 \mu \mathrm{L} / \mathrm{min}$. A blank solution of ammonium bicarbonate was utilized between each sample to avoid peak carry-over between runs. The mass spectrometer was calibrated using Pierce ${ }^{\mathrm{TM}}$ Negative Ion Calibration Solution from Thermo Scientific, USA. The results were analyzed using software Xcalibur (Thermo Scientific).

Synthesis of O-cyclohexyl, O-methyl, O-(p-nitrophenyl) Phosphate. A stirred solution of cyclohexanol ( $0.52 \mathrm{~mL}, 5.0 \mathrm{mmol}, 1.0$ equiv) in anhydrous diethyl ether $(7.5 \mathrm{~mL})$ was chilled to $-78{ }^{\circ} \mathrm{C}$ in a dry ice bath. $2.0 \mathrm{ml}$ of $n$-butyllithium (2.5 $\mathrm{M}$ in hexanes, $5.0 \mathrm{mmol}, 1.0$ equiv) was added. The solution was stirred for 30 minutes and transferred via cannula to another flask at -78 ${ }^{\circ} \mathrm{C}$ that contained methyl dichlorophosphate $(85 \%, 0.59 \mathrm{~mL}, 5.0 \mathrm{mmol}, 1.0$ equiv) and anhydrous diethyl ether $(25 \mathrm{~mL})$. The dry ice bath was removed and the reaction was allowed to warm to ambient temperature $\left(21^{\circ} \mathrm{C}\right)$. After stirring for $6 \mathrm{~h}, 4$-nitrophenol (0.696 g, $5.0 \mathrm{mmol}, 1.0$ equiv) was added at room temperature followed by the addition of dry triethylamine $(0.69 \mathrm{~mL}, 5.0$ mmol, 1.0 equiv). The yellow solution was stirred for $10 \mathrm{~h}$ and filtered. After concentration, the residue was purified by silica gel column chromatography (hexanes/ethyl acetate, 4:1 $\rightarrow$ 2:1) to give $0.81 \mathrm{~g}(51 \%)$ of $O$-cyclohexyl $O$-methyl $O$-( $p$-nitrophenyl) phosphate as a colorless oil. ${ }^{1} \mathrm{H}$ NMR $\left(600 \mathrm{MHz}, \mathrm{CDCl}_{3}\right) \delta 8.41-8.00(\mathrm{~m}, 2 \mathrm{H}), 7.54-7.28(\mathrm{~m}, 2 \mathrm{H}), 4.56-4.45(\mathrm{~m}, 1 \mathrm{H}), 3.84$ $(\mathrm{d}, J=11.5 \mathrm{~Hz}, 3 \mathrm{H}), 2.04-1.92(\mathrm{~m}, 1 \mathrm{H}), 1.92-1.84(\mathrm{~m}, 1 \mathrm{H}), 1.79-1.64(\mathrm{~m}, 2 \mathrm{H}), 1.62-1.50$ $(\mathrm{m}, 2 \mathrm{H}), 1.50-1.43(\mathrm{~m}, 1 \mathrm{H}), 1.41-1.26(\mathrm{~m}, 2 \mathrm{H}), 1.27-1.15(\mathrm{~m}, 1 \mathrm{H}) ;{ }^{13} \mathrm{C} \mathrm{NMR}(150 \mathrm{MHz}$, $\left.\mathrm{CDCl}_{3}\right) \delta 155.6\left(\mathrm{~d},{ }^{2} J_{\mathrm{C}-\mathrm{P}}=6.1 \mathrm{~Hz}\right), 144.6,125.69(2 \mathrm{C}), 120.6\left(\mathrm{~d},{ }^{3} J_{\mathrm{C}-\mathrm{P}}=5.5 \mathrm{~Hz}, 2 \mathrm{C}\right), 79.4(\mathrm{~d}$, $\left.{ }^{2} J_{\mathrm{C}-\mathrm{P}}=6.6 \mathrm{~Hz}\right), 55.0\left(\mathrm{~d},{ }^{2} J_{\mathrm{C}-\mathrm{P}}=6.1 \mathrm{~Hz}\right), 33.3\left(\mathrm{~d},{ }^{3} J_{\mathrm{C}-\mathrm{P}}=4.5 \mathrm{~Hz}\right), 33.2\left(\mathrm{~d},{ }^{3} J_{\mathrm{C}-\mathrm{P}}=4.5 \mathrm{~Hz}\right), 25.0$, $23.4(2 \mathrm{C}) ;{ }^{31} \mathrm{P}\left\{{ }^{1} \mathrm{H}\right\} \quad \mathrm{NMR}\left(242 \mathrm{MHz}, \mathrm{CDCl}_{3}\right) \delta-6.9$ (s); HRMS (ESI) calculated for $\mathrm{C}_{13} \mathrm{H}_{18} \mathrm{NO}_{6} \mathrm{PNa}^{+}[\mathrm{M}+\mathrm{Na}]^{+} 338.0769$, found 338.0767.

Synthesis of O-cyclohexyl, O-methyl, O-(p-nitrophenyl) Thiophosphate. Lawesson's reagent $(1.07 \mathrm{~g}, 2.65 \mathrm{mmol}, 1.1$ equiv) was added to a stirred solution of the O-cyclohexyl Omethyl O-( $p$-nitrophenyl) phosphate $(0.76 \mathrm{~g}, 2.4 \mathrm{mmol}, 1.0$ equiv) in anhydrous toluene $(60 \mathrm{~mL})$, and the mixture was heated at $100{ }^{\circ} \mathrm{C}$ for $42 \mathrm{~h}$. The reaction was allowed to cool to ambient temperature $\left(21^{\circ} \mathrm{C}\right)$ and concentrated in vасио. The residue was purified by silica gel column chromatography (hexanes/ethyl acetate, $20: 1 \rightarrow 10: 1$ ) to give $O$-cyclohexyl $O$-methyl $p$ nitrophenylthiolphosphate $(388.2 \mathrm{mg}, 49 \%)$ as a colorless oil. ${ }^{1} \mathrm{H} \mathrm{NMR}\left(300 \mathrm{MHz}, \mathrm{CDCl}_{3}\right) \delta$ $8.32-8.10(\mathrm{~m}, 2 \mathrm{H}), 7.43-7.29(\mathrm{~m}, 2 \mathrm{H}), 4.70-4.46(\mathrm{~m}, 1 \mathrm{H}), 3.84(\mathrm{~d}, J=14.0 \mathrm{~Hz}, 3 \mathrm{H}), 2.10-$ $1.84(\mathrm{~m}, 2 \mathrm{H}), 1.84-1.67(\mathrm{~m}, 2 \mathrm{H}), 1.66-1.45(\mathrm{~m}, 3 \mathrm{H}), 1.44-1.31(\mathrm{~m}, 2 \mathrm{H}), 1.30-1.17(\mathrm{~m}$, $1 \mathrm{H}) ;{ }^{13} \mathrm{C}$ NMR $\left(75 \mathrm{MHz}, \mathrm{CDCl}_{3}\right) \delta 155.4\left(\mathrm{~d},{ }^{2} J_{\mathrm{C}-\mathrm{P}}=7.2 \mathrm{~Hz}\right), 144.6,125.3\left(\mathrm{~d},{ }^{4} J_{\mathrm{C}-\mathrm{P}}=0.7 \mathrm{~Hz}, 2 \mathrm{C}\right)$, $121.5\left(\mathrm{~d},{ }^{3} J_{\mathrm{C}-\mathrm{P}}=5.4 \mathrm{~Hz}, 2 \mathrm{C}\right), 79.8\left(\mathrm{~d},{ }^{2} J_{\mathrm{C}-\mathrm{P}}=6.2 \mathrm{~Hz}\right), 54.5\left(\mathrm{~d},{ }^{2} J_{\mathrm{C}-\mathrm{P}}=6.0 \mathrm{~Hz}\right), 32.9\left(\mathrm{~d},{ }^{3} J_{\mathrm{C}-\mathrm{P}}=4.6\right.$ $\mathrm{Hz}), 32.8\left(\mathrm{~d},{ }^{3} J_{\mathrm{C}-\mathrm{P}}=5.1 \mathrm{~Hz}\right), 24.9,23.4(2 \mathrm{C}) ;{ }^{31} \mathrm{P}\left\{{ }^{1} \mathrm{H}\right\}$ NMR $\left(121 \mathrm{MHz}, \mathrm{CDCl}_{3}\right) \delta 63.1(\mathrm{~s})$. HRMS (ESI) calculated for $\mathrm{C}_{13} \mathrm{H}_{18} \mathrm{NO}_{5} \mathrm{PSNa}^{+}[\mathrm{M}+\mathrm{Na}]^{+} 354.0541$, found 354.0557.

NMR Analysis. ${ }^{1} \mathrm{H},{ }^{13} \mathrm{C}$, and ${ }^{31} \mathrm{P}$ NMR spectra were recorded at $300 \mathrm{MHz}$ or $600 \mathrm{MHz}\left({ }^{1} \mathrm{H}\right.$ NMR), 75.4 MHz or $150.9\left({ }^{13} \mathrm{C} \mathrm{NMR}\right)$, and $121.4 \mathrm{MHz}$ or $242.9 \mathrm{MHz}\left({ }^{31} \mathrm{P} \mathrm{NMR}\right)$, respectively. Chemical shifts are reported as $\delta$ values in ppm, coupling constants $(\mathrm{J})$ are reported in Hertz $(\mathrm{Hz})$, and multiplicity follows convention. For ${ }^{1} \mathrm{H}$ and ${ }^{13} \mathrm{C}$ NMR spectra, the residual solvent 
peak was used as an internal reference $\left({ }^{1} \mathrm{H}\right.$ NMR: $\delta 7.26$ for $\mathrm{CDCl}_{3} ;{ }^{13} \mathrm{C}$ NMR: $\delta 77.16$ for $\left.\mathrm{CDCl}_{3}\right) .{ }^{31} \mathrm{P}$ NMR spectra were referenced to an external standard $\left(\mathrm{H}_{3} \mathrm{PO}_{4}: 0.0 \mathrm{ppm}\right)$. For enzyme catalyzed reactions unreacted O-cyclohexyl O-methyl $p$-nitrophenylthiophosphate was used as an internal standard. (S)-(-)- $\alpha$-methylbenzylamine was added as a chiral shift agent to determine the stereochemistry of the enzyme derived O-cyclohexyl O-methyl thiophosphate as previously described. ${ }^{3,4}$

Determination of Stereoselectivity of Sb-PTE. $1 \mathrm{~mL}$ total volume reactions with $50 \mathrm{mM}$ Ches (pH 9), $25 \mu \mathrm{M} O$-cyclohexyl $O$-methyl O-( $p$-nitrophenyl) thiophosphate and $2.5 \% \mathrm{DMF}$ were followed by the release of $p$-nitrophenol $\left(\mathrm{E}_{400}=17,000 \mathrm{M}^{-1} \mathrm{~cm}^{-1}\right)$ in a Spectramax 340 UV/Vis spectrophotometer (Molecular Devices). Reactions were initiated by the addition of either 12 nM G60A $P d$-PTE, 770 nM VRN-VQFL-I106G/L308S Pd-PTE ${ }^{5}$, or $34 \mu \mathrm{M} S b$-PTE. Once the G60A $P d$-PTE catalyzed reaction reached apparent completion, $770 \mathrm{nM}$ of VRNVQFL-I106G/L308S Pd-PTE was added resulting in a second phase of hydrolysis. Once the reaction initiated with $S b$-PTE had reached apparent completion $12 \mathrm{nM}$ G60A $P d$-PTE was added and the reaction followed an additional $300 \mathrm{~s}$, then $770 \mathrm{nM}$ VRN-VQFL-I106G/L308S $P d$-PTE was added.

Total Hydrolysis of O-cyclohexyl O-methyl O-(p-nitrophenyl) Thiophosphate by KOH. 10 mg O-cyclohexyl O-methyl p-nitrophenylthiolphosphate was dissolved in $4 \mathrm{~mL}$ of ethanol and 1 $\mathrm{mL}$ of $5 \mathrm{M} \mathrm{KOH}$ was added. The reaction was stirred overnight at room temperature. $20 \mathrm{~mL}$ of water was added and the ethanol was evaporated in vacuo. The remaining aqueous solution was acidified by drop wise addition of $1 \mathrm{M} \mathrm{HCl}$ until the $\mathrm{pH}$ was below 2 . The resulting Ocyclohexyl, O-methyl thiolphosphate was extracted and analyzed by NMR as below.

Total Hydrolysis of O-cyclohexyl O-methyl O-(p-nitrophenyl) Thiophosphate by Pd-PTE. $10.8 \mathrm{mg}$ of O-cyclohexyl O-methyl p-nitrophenylthiolphosphate was dissolved in $1 \mathrm{~mL}$ DMF and added to a $20 \mathrm{~mL}$ total volume reaction with $50 \mathrm{mM}$ Ches $(\mathrm{pH} 9), 100 \mathrm{mM} \mathrm{NaCl}$ and 0.55 $\mathrm{mg}$ of G60A $P d$-PTE and reaction proceeded for $1 \mathrm{hr}$ at room temperature. When reaction was $50 \%$ complete $10 \mathrm{~mL}$ was removed and acidified with $1 \mathrm{~mL}$ of $1 \mathrm{M}$ HCL to isolate the G60A $P d$ hydrolysis product. To the remaining $10 \mathrm{~mL}$ reaction, $3.4 \mathrm{mg}$ of $\mathrm{L}_{7 \mathrm{ep}} 3 \mathrm{aG}^{5} P d$-PTE was added. This reaction continued for $3.5 \mathrm{hr}$ at room temperature. When the reaction had reached completion it was acidified by addition of $1 \mathrm{~mL} 1 \mathrm{M} \mathrm{HCl}$. The G60A hydrolysis product and the total $P d$-hydrolysis products were isolated and analyzed as described below.

Isolation of the Individual Enantiomers of O-cyclohexyl O-methyl Thiophosphate by $P d$ PTE Hydrolysis. $20 \mathrm{mg}$ of O-cyclohexyl O-methyl p-nitrophenylthiolphosphate was dissolved in $400 \mu \mathrm{L}$ of methanol and added to a $20 \mathrm{~mL}$ total volume reaction with $50 \mathrm{mM}$ Ches (pH 9), 100

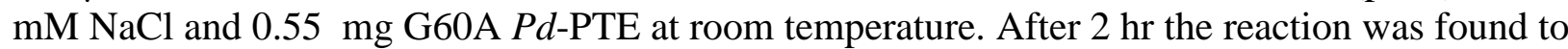
be $45 \%$ complete. Methanol was removed by evaporation in vacuo, and the reaction was extracted 3 times with dichloromethane to remove unreacted substrate $(\sim 100 \mathrm{~mL})$. The aqueous phase was acidified with $1 \mathrm{~mL} 1 \mathrm{M} \mathrm{HCl}$ and product isolated as below. The organic phase was evaporated, the resulting residue dissolved in $400 \mu \mathrm{L}$ of methanol, and added to a $20 \mathrm{~mL}$ total volume reaction with $50 \mathrm{mM}$ Ches, $100 \mathrm{mM} \mathrm{NaCl}$ and $5.4 \mathrm{mg}$ of L7ep3aG $P d$-PTE. The reaction proceeded for 60 hours at room temperature. The reaction mixture was then acidified by addition of $1 \mathrm{~mL}$ of $1.0 \mathrm{M} \mathrm{HCl}$ and product isolated as below. 
Isolation of the Sb-PTE Hydrolysis Product of O-cyclohexyl O-methyl p-nitrophenyl Thiophosphate. O-cyclohexyl O-methyl p-nitrophenylphosphate $(10.8 \mathrm{mg})$ was dissolved in 1 $\mathrm{mL}$ DMF, and added to a $20 \mathrm{~mL}$ total volume reaction containing $50 \mathrm{mM}$ Ches (pH 9), $100 \mathrm{mM}$ $\mathrm{NaCl}$, and $133 \mathrm{mg}$ of $S b$-PTE. The reaction proceeded to approximately $35 \%$ completion in 20 hours at room temperature. A total of $10 \mathrm{~mL}$ of the reaction was removed and acidified with 1 $\mathrm{mL}$ of $1 \mathrm{M} \mathrm{HCl}$. The product was isolated as below.

Extraction of O-cyclohexyl O-methyl Thiophosphate from Aqueous Solution. For reaction where methanol was used it was removed in vacuo prior to acidification. Once reactions were complete they were acidified with $\mathrm{HCl}$ and the $\mathrm{pH}$ was verified to be below 2 . The aqueous solutions were then extracted with dichloromethane $(\sim 300 \mathrm{~mL})$ and dried over $\mathrm{NaSO}_{4}$. Solvent was then removed and the resulting residues dissolved in $\mathrm{CDCl}_{3}(\sim 1.5 \mathrm{~mL})$. (S)-(-)- $\alpha-$ methylbenzylamine (1.6 eq of starting material) was added as a chiral shift reagent, and ${ }^{31} \mathrm{P}$ NMR spectra were recorded. 
88 QVVIGPGDRP ETGLQGQTTI EDVVSGRSKL PYHAGVRLVG RTDIWNRGGN LQLSWVDQCA YVSTFKQAGP ITANSRSALF 168 LREPAGVAVI DVRDPRAPKP VRLLRDRGSI DAVETMHAIA APGRKVLVAG AYSGGIAGRG EEDAAWLSIY DASNCLNPKL 248 QSEFKWPANI HMVTISPNGR RVYGTEVVPG LGSGKGGLHV LDISDMKRPR YLGRFGVTRP NGLTAGFTPH EVSISHDERR 328 IYAAVLASET GDVPVGASIL ASDGDVPVEN GSVYILDNSD IVDGRSQPKM RLVGEAKQGG FHSVVPASIN GVPHLVGAAE 408 LGACPGTWPR IINIADEKNP KIVGEFKLQM NIKENCDAIR FTPRKEDPYA SFIPIPDITA RLGAVGSHFN DVDDARNTRL 488 GLFPFFAGGV RIVDLRDPTK PVEVGYYKPG ANPDTPLSGN GLNWTGLNDQ VTDGCMSHVR YVPESGHIWF ACVTTGFHVV 568 ELNPDLRARL GFPTVKLEHH HHHH

Figure S1. Sequence for recombinant $S b$-PTE used in MS analysis. 
Table S1. Predicted and observed masses for peptides found from Sb-PTE.

\begin{tabular}{|c|c|c|c|}
\hline Peptide & $\begin{array}{c}\text { Predicted } \\
\text { Mass }\end{array}$ & $\begin{array}{l}\text { Observed } \\
\text { Mass }{ }^{16} \mathrm{O}^{\mathrm{a}}\end{array}$ & $\begin{array}{l}\text { Observed } \\
\text { Mass }{ }^{18} O^{a}\end{array}$ \\
\hline 88-QVVIGPGDRPETGLQGQTTIEDVVSGRS-114 & 2808.44 & 2808.44 & 2808.44 \\
\hline 125-RLVGRTDIWNRG-134 & 1229.68 & 1229.67 & 1229.67 \\
\hline 129-RTDIWNRG-134 & 804.39 & 804.39 & 804.40 \\
\hline 135-RGGNLQLSWVDQC(Carbamidomethyl)AYVSTFKQ-153 & 2173.02 & 2173.04 & 2173.03 \\
\hline 154-KQAGPITANSRS-163 & 1014.52 & 1014.53 & NO \\
\hline 164-RSALFLRE-169 & 706.42 & 706.42 & 706.42 \\
\hline 170-REPAGVAVIDVRD-180 & 1125.62 & 1125.62 & 1125.62 \\
\hline 184-RAPKPVRL-189 & 667.42 & 667.42 & 667.42 \\
\hline 190-RLLRD-192 & 401.28 & NO & 401.28 \\
\hline 193-RDRGSIDAVETMHAIAAPGRK-211 & 1966.97 & 1966.97 & 1966.98 \\
\hline 195-RGSIDAVETMHAIAAPGRK-211 & 1695.84 & 1695.84 & 1695.84 \\
\hline 195-RGSIDAVETMHAIAAPGRKV-212 & 1823.95 & 1823.94 & NO \\
\hline 227-RGEEDAAWLSIYDASNC(Carbamidomethyl)LNPKL-246 & 2253.00 & 2253.01 & 2253.01 \\
\hline 247-KLQSEFKW-252 & 751.39 & 751.39 & 751.39 \\
\hline 268-RRVYGTEVVPGLGSGKG-282 & 1518.81 & 1518.82 & NO \\
\hline 269-RVYGTEVVPGLGSGKG-282 & 1362.72 & 1362.72 & 1362.72 \\
\hline 283-KGGLHVLDISDMKR-294 & 1284.65 & 1284.66 & 1284.66 \\
\hline 298-RYLGRF-301 & 508.28 & 508.28 & 508.28 \\
\hline 302-RFGVTRPNGLTAGFTPHEVSISHDERR-326 & 2724.34 & 2724.34 & 2724.34 \\
\hline 328-RIYAAVLASETGDVPVGASILASDGDVPVENGSVYILDNSDIVDGRS-372 & 4533.23 & 4533.25 & 4533.25 \\
\hline 385-KQGGFHSVVPASINGVPHLVGAAELGAC(Carbamidomethyl)PGTWPRI-417 & 3338.66 & 3338.68 & 3338.68 \\
\hline $418-R I I N I A D E K N-425$ & 915.51 & 915.51 & 915.51 \\
\hline 429-KIVGEFKL-434 & 692.39 & 692.39 & 692.39 \\
\hline 435-KLQMNIKE-440 & 746.42 & 746.42 & 746.42 \\
\hline 441-KENC(Carbamidomethyl)DAIRF-447 & 877.38 & 877.38 & 877.38 \\
\hline 448-RFTPRK-451 & 520.28 & 520.28 & 520.28 \\
\hline 452-RKEDPYASFIPIPDITARL-468 & 1932.99 & 1933.00 & 1933.00 \\
\hline 469-RLGAVGSHFNDVDDARN-483 & 1572.74 & 1572.74 & 1572.74 \\
\hline 487-RLGLFPFFAGGVRI-498 & 1280.71 & 1280.71 & 1280.71 \\
\hline 499-RIVDLRDPTKPVEVGYYKPGANPDTPLSGNGLNWTGLNDQVTDGC(Carbamidomethyl)MSHVRY-547 & 5353.57 & NO & 5353.6 \\
\hline 504-RDPTKPVEVGYYKPGANPDTPLSGNGLNWTGLNDQVTDGC(Carbamidomethyl)MSHVRY-547 & 4757.21 & 4757.23 & 4757.23 \\
\hline 548-RYVPESGHIWFAC(Carbamidomethyl)VTTGFHVVELNPDLRA-574 & 3143.53 & 3143.54 & 3143.54 \\
\hline 577-RLGFPTVKL-583 & 761.45 & 761.45 & 761.45 \\
\hline 584-KLEHHНHНH-591 & 1083.50 & 1083.49 & 1083.49 \\
\hline \multicolumn{4}{|l|}{ M+2 Peptides observed } \\
\hline 441-KENC(Carbamidomethyl)DAIRFTPR-451 & 1380.65 & 1380.65 & NO \\
\hline 453-KEDPYASFIPIPDITARLGAVGSHFNDVDDAR-483 & 3360.63 & 3360.63 & 3360.63 \\
\hline $\begin{array}{l}\text { M+4 Peptides observed } \\
\text { None Found }\end{array}$ & & & \\
\hline
\end{tabular}



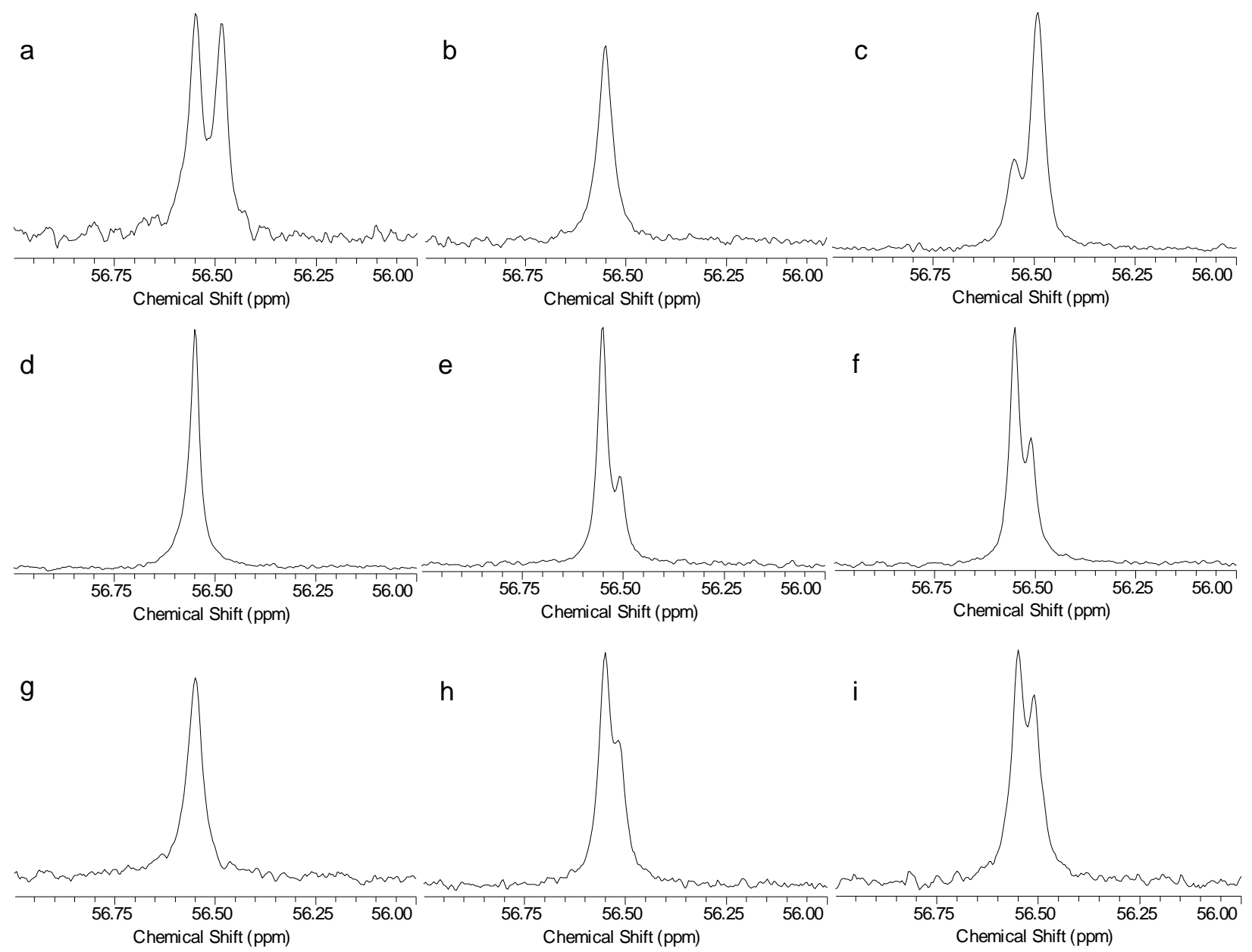

Figure S2. ${ }^{31} \mathrm{P}$ NMR spectra of O-methyl O-cyclohexyl thiophosphate in the presence of $(S)-\alpha-$ methylbenzylamine. O-methyl O-cyclohexyl thiophosphate is derived from the hydrolysis of O-methyl $\mathrm{O}$-cyclohexyl O-( $p$-nitrophenyl) phosphate. Unless otherwise noted the reactions were carried out with the racemic substrate. (a) Product produced from the total hydrolysis of the substrate with $1 \mathrm{M} \mathrm{KOH}$. (b) Product produced by the stereoselective hydrolysis of the substrate by $S b$-PTE. (c) Product produced by the hydrolysis of isolated $S_{\mathrm{P}}$-enantiomer by the L7ep3aG variant of $P d$-PTE. (d) Product produced by the stereoselective hydrolysis of the substrate by the G60A variant of $P d$-PTE. (e) Mixture of $700 \mu \mathrm{L}$ $(\sim 13 \mu$ moles) of the G60A Pd-PTE hydrolyzed sample (shown in Figure S2d) mixed with $200 \mu \mathrm{L}(\sim 5$ $\mu$ moles) of the sample made from the L7ep3aG variant of Pd-PTE (shown in Figure S2c). (f) Mixture of $700 \mu \mathrm{L}(\sim 13 \mu$ moles) of G60A $P d$-PTE sample (shown in Figure S2d) mixed with $300 \mu \mathrm{L}(\sim 7 \mu$ moles) of sample from L7ep3aG hydrolysis (shown in Figure S2c). (g) Mixture of $350 \mu \mathrm{L}$ ( $5 \mu$ moles) of $S b$ PTE hydrolysis product (shown in Figure S2b) mixed with $350 \mu \mathrm{L}(\sim 7$ umoles) of G60A Pd-PTE product (shown in Figure S2d). (h) Mixture of $350 \mu \mathrm{L}(\sim 5 \mu$ moles) of $S b$-PTE hydrolysis product (shown in Figure S2b) mixed with $350 \mu \mathrm{L}$ ( 7 $\mu$ moles) of G60A Pd-PTE product (shown in Figure S2d) and $150 \mu \mathrm{L}(\sim 4 \mu$ moles) from L7ep3aG hydrolysis (shown in Figure S2c). (i) Mixture of $350 \mu \mathrm{L}(\sim 5$ $\mu$ moles) of $S b$-PTE hydrolysis product (shown in Figure S2b) mixed with $350 \mu \mathrm{L}$ ( $\sim 7 \mu$ moles) of G60A $P d$-PTE product (shown in Figure S2d) and $250 \mu \mathrm{L}(\sim 6 \mu$ moles) from L7ep3aG hydrolysis (shown in Figure S2c). 
References

(1) Bigley, A. N.; Xu, C.; Henderson, T. J.; Harvey, S. P.; Raushel, F. M. J Am Chem Soc 2013, 135, 10426.

(2) Shevchenko, A.; Tomas, H.; Havlis, J.; Olsen, J. V.; Mann, M. Nat Protoc 2006, 1, 2856.

(3) Lewis, V. E.; Donarski, W. J.; Wild, J. R.; Raushel, F. M. Biochemistry 1988, 27, 1591.

(4) Mikolajczyk, M.; Omelanczuk, J.; Leitloff, M.; Drabowicz, J.; Ejchart, A.; Jurczak, J. Journal of the American Chemical Society 1978, 100, 7003. 5502.

(5) Bigley, A. N.; Mabanglo, M. F.; Harvey, S. P.; Raushel, F. M. Biochemistry 2015, 54, 